\title{
Role of Industrialization on Economic Growth: The Experience of Senegal (1960-2017)
}

\author{
Cisse Ndiaya ${ }^{1 *}$, Kangjuan Lv ${ }^{2 \#}$ \\ ${ }^{1}$ School of Economics, Regional Economics as Research Field, Shanghai, China \\ ${ }^{2}$ SHU-UTS SILC Business School, Shanghai, China \\ Email: ndiayacisse42@outlook.fr, "lvkangjuan@shu.edu.cn
}

How to cite this paper: Ndiaya, C. and Lv, K.J. (2018) Role of Industrialization on Economic Growth: The Experience of Senegal (1960-2017). American Journal of Industrial and Business Management, 8, 2072-2085. https://doi.org/10.4236/ajibm.2018.810137

Received: July 19, 2018

Accepted: October 6, 2018

Published: October 9, 2018

Copyright ( 92018 by authors and Scientific Research Publishing Inc. This work is licensed under the Creative Commons Attribution International License (CC BY 4.0).

http://creativecommons.org/licenses/by/4.0/

(c) (i) Open Access

\begin{abstract}
The aim of this study is to contribute to the investigation of the impact of industrialization on economic growth by analyzing the Senegalese manufacturing firms. The paper utilized the secondary data drawn from the World Bank (WDI 2015) and the National Agency of Statistic and Demography in Senegal (ANSD) and covered the period between 1960 and 2017. It will employ the Ordinary Least Square (OLS) techniques in estimating the relationship between industrial output, inflation rate, FDI, Foreign Exchange Rate and economic growth, after which ADF unit root test was conducted using Breusch-Godfrey serial correlation LM test and Breusch-Pagan-Godfrey heteroskedasticity test. The econometric analysis has shown that the increase of industrial output will increase economic growth in Senegal. Therefore, there is significant relationship between industrial development and Senegalese economy growth. However, the result revealed that industrialization will go a long way in stimulating economic growth. Based on these results, we have recommended some policy measures in order to boost industrial output by improving the overall productivity of all the sectors and ensure sustainable development.
\end{abstract}

\section{Keywords}

Industrialization, Growth, Senegal, GDP, OLS

\section{Introduction}

\subsection{Background of the Study}

Industrialization, which the industrial revolution has placed at the heart of structural changes, has consistently raised the levels of production and employ-

*First author. 
ment, which has led to unprecedented income growth. So promoting the development of the industrial sector can be a key to achieving sustainable development. It is indeed now well established in the growth and development literature that there is as strong relation between the growth of manufacturing output and the growth of GDP [1] (Pacheco-lopez ad thirlwall, 2013).

The impact of industrialization on economic development has been widely studied. All historical examples of success in economic development and catch-up since 1870 have been able to grow and accumulate wealth by investing in their industries [2] (Szirmai, (2012)). It brings about increased volume and varieties of manufactured goods resulting in increased employment and improved standard of living of the citizens. In the process of economic growth [3] Kaldor (1967) suggested that it is the industrial sector which plays the role of engine of growth, as the potential productivity growth is the highest in this sector. Then industrial sector can power the economy with the right policies, it will transform and sluggish recovery into an economic resurgence.

Indeed, it is recognized that the African countries, as other countries, will find difficult to create the wealth necessary for the eradication of extreme poverty without a real industrialization capable of generating added value. In Africa, the word industry is used essentially as a synonym for manufacturing as in many other developing countries. It refers usually to changing of raw materials into products of more value. However, industry refers to an organized human skill and efforts to produce something more valuable and useful from the gifts of natural resources and primary products. It refers to the process of manufacturing.

Since independence, Senegal has successively defined several industrial development strategies in order to give importance to the sector and to promote economic growth and redistribution of income. Senegal's journey was towards industrialization state, immediately after its independence when the country adopted the import substitution in 1960. This strategy comes into being because of the belief that through industrialization, the Senegal's government would be able to promote the emergence and expansion of domestic industries by replacing major such as textile, shoes and food. The share of industrial sector in Senegal remains stagnant and sometimes decline, moreover, most of the Kaldorian studies for developing or emerging countries increase rapidly.

The industrial sector in particular manufacturing is considered to be critical in this study in order to enable Senegal to an economic development. This choice is because Senegal's economy is driven by mining, manufacturing construction, tourism, fisheries and agriculture, which are the primary sources of employment in rural areas. The country's key export industries include phosphate mining, fertilizer production, agricultural products and commercial fishing and Senegal is also working on oil exploration projects.

While various studies such as [4] World Bank (2012), focus on the performance or business environment of the industrial sector, few studies have focused 
on its impact on economic development. To the best of my knowledge, there is no research study talking typically about this topic in Senegal. This paper addresses the question of the role of industrialization on economic development in Senegal.

To carry out the current study, we will introduce the subject of the study in Section 1, giving background on the above by the study's background, objectives, research questions and hypotheses in Section 2. The rest of the work is classified into, trade policy reforms and manufacturing performances in Senegal Section 3; literature review Section 4; research methodology Section 5; results interpretation Section 6; and finally conclusion and recommendations in the Section 7 [5] (Abiola \& Egbuwalo, 2010).

\subsection{Objectives of the Study}

The general objective of this paper was to find out the impact of industrialization on economic growth in Senegal. While specific objectives include:

1) To appraise the impact of the industrial sector on the economic growth and development of Senegal;

2) To review the major obstacles of Senegalese industrial development, in particular the manufacturing sector;

3) To identify the theoretical bases and principles that can be used for promoting and redressing the decline in the industrial sector in Senegal.

\subsection{Research Questions}

The paper would also explore these questions as following:

1) What extent has the manufacturing sector contributed to the economic growth?

2) What are the factors that affect the industrialization process and the performance of manufacturing firms in Senegal?

3) What major evolving concepts could be adopted to promote and redress the industrial development?

\section{Background: The Policy Reforms and Industrial Performances in Senegal}

\subsection{The Evolution of Senegalese Industrial Policies}

The industrial policies carried out in Senegal have been spread over time. They have started since independence and include essentially the pre-1986 industrial policies, the new Industrial Policy (NPI) of 1986 and the Industrial Redeployment Policy (PRI) from 2004. The Senegalese industrial sector also experienced industrial policies under regional, and international sectors.

\subsubsection{Pre-1986 Industrial Policies}

Since independence, various strategies have been implemented to revitalize the Senegalese industrial sector within the framework of economic development plans. Between 1961 and 1969, the priority was the creation of large industrial 
enterprises and the mobility of capital for the purpose of import-substituting industrialization (substitution policy). The period 1969-1973 was marked by a need for the development of small and medium-sized enterprises by supporting the private initiative.

In 1974, the Senegalese industrial sector became the object of the creation of the Dakar industrial free Zone (ZFID) which had to promote, among other things, job creation and technological development.

However, Senegal's economic and social situation was critical after these various policies were carried out. The growth rate of industrial production slowed from $8.1 \%$ to $0.3 \%$ between 1981 and 1985 (Source: ANSD). The industry thus faced to difficulties and has involving a new policy.

\subsubsection{The New Industrial Policy (NPI)}

In 1986 the Government in the framework of structural adjustment developed the NPI Programs (SAPs). The NPI aimed at three objectives: to improve the competitiveness of the industrial sector, to develop industrial activities with high added value and to diversify the industrial fabric. The implementation of this new policy consisted of the rationalization of export protection (including the abolition of non-tariff protections), the promotion of investment and the improvement of the institutional environment and Technology of companies, the acceleration of industrial recovery.

However, the actions carried out with this new policy have not given the expected results. Industrial production has declined over the period of implementation of industrial policy. The growth rate of industrial production increased from 9\% to 4\% between 1986 and 1999; Industrial production experienced decreases in $1991(-3 \%)$ and $1993(-8 \%)$, in addition to the jobs loses and the closure of some factories. As a result, Senegal decided to pursue an industrial redeployment policy for the industrial sector in the years 2000 .

\subsubsection{The Industrial Redeployment Policy (PRI)}

The objective of this industrial policy developed in 2004 is the upgrading of industrial enterprises and endogenous development. The upgrade is to raise the level of performance of industrial companies. It will strengthen the competitiveness of the Senegalese industry by improving the competitive capacity of industrial enterprises in the face of economic openness. Endogenous industrial development concerns the creation of microphones, small and medium-sized enterprises (MSMEs); the balanced implementation of industrial enterprises in the national territory and the valorisation of national resources with a view of a dynamic, [6] Senegal PRI (2005).

However, the PRI is confronted with changing the business environment because of the process of integration of the West African Economic and monetary Union (UEMOA). The Union has initiated a common industrial policy.

\subsubsection{The UEMOA Common Industrial Policy (PIC)}

The UEMOA countries adopted in December 1999 a common Industrial Policy 
(PIC) for the restructuring of industrial units, the promotion of a coordinated industrial fabric, the improvement of the competitiveness of enterprises and the sustainable industrial development.

This common industrial policy has three principles: competition, solidarity and cooperation between the countries of the Union. It contributes to the integration of members economies into the globalization process by giving birth to a common external tariff (TEC) and a common commercial policy (PCC). This same type of industrial policy is initiated within the Economic Community of West African States (ECOWAS). This is the common industrial policy of West Africa (PICAO) developed in 2007.

\subsection{Senegalese Industrial Sector Performances}

A study on "The state of the industry in Senegal over the period 2009-2013" commissioned by the Ministry of Industry and Mines and carried out by the Senegalese National Agency of Statistics and Demography [7] (ANSD) in 2016, reveals that the Senegalese industrial sector has about 1270 companies. Small and medium-sized industries account for an average of $92.5 \%$ of the total.

Figure 1 shows that the sectors that recorded the most important growth rates were the edible fats industry, the manufacturing of beverages, followed by the manufacturing of transportation equipment and the manufacturing of cereal food products. However, their contribution to the total value added is very low no more than 5 per cent in all. At the same time, the sectors whose share in total industrial value added diminished the most over the period 2005 to 2010 are the woodworking and the manufacture of wooden products, the leather processing and manufacturing and the cotton and textiles industry. Each of them accounts for 0.06 per cent, 0.12 per cent and 1.45 per cent of the total value added over the period.

\subsection{Senegalese Industry Obstacles}

Figure 2 aims to describe the features of the main obstacles to productivity and growth of industrial development in Senegal by using the Senegal's [8] Doing Business results against better performing countries. Comparing countries (Cape Verde, Morocco, India, and Ghana) are chosen from the same category as Senegal i.e. Lower Middle Income countries according to the World Bank classification.

The 2014 Doing Business Report summarized in Figure 2 has shown that improvements are necessary in these following areas: connections; credit access; informality; property registration; protection of investors; tax payment and; contract enforcement to make Senegal catch up the other countries in term of industrialization. Also Senegal obtained poor results compared to the other countries of the sample for the credit access and investors protection indicators. With regards to credit access, improvements are needed in the coverage, extent and quality of credit information available through public credit registries and private credit bureaus.

Clearly, tremendous efforts are to be made in areas such as electricity connection 


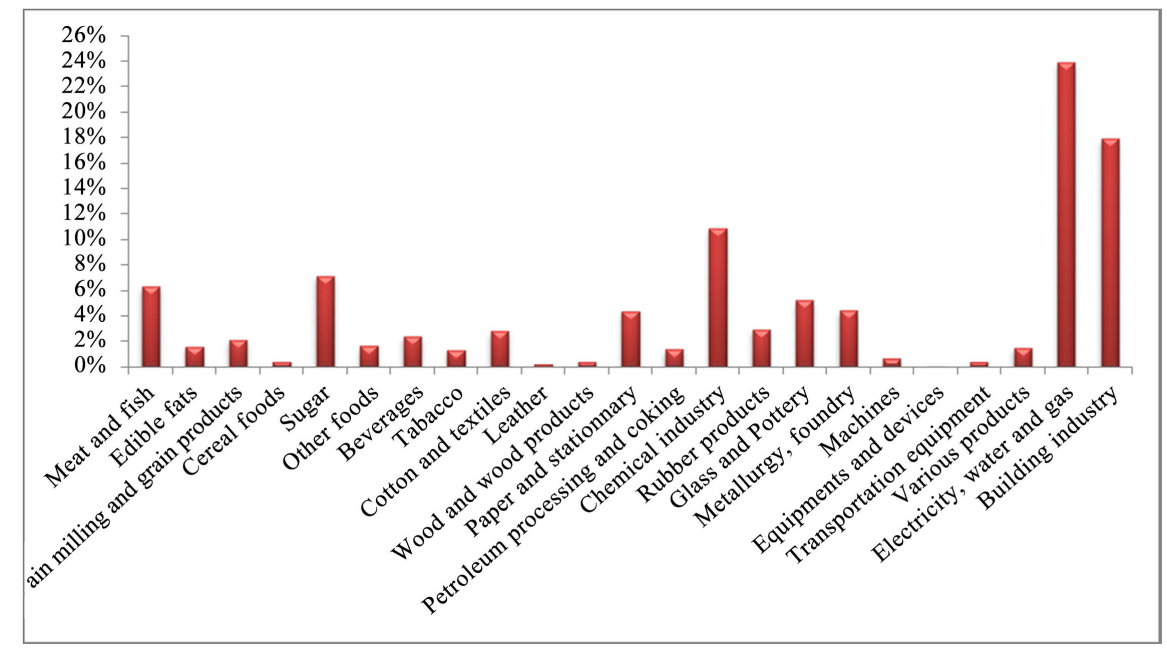

Figure 1. Structure of the value added by industrial sector over the last 30 years, 1985-2015. Source: ANSD (various years).

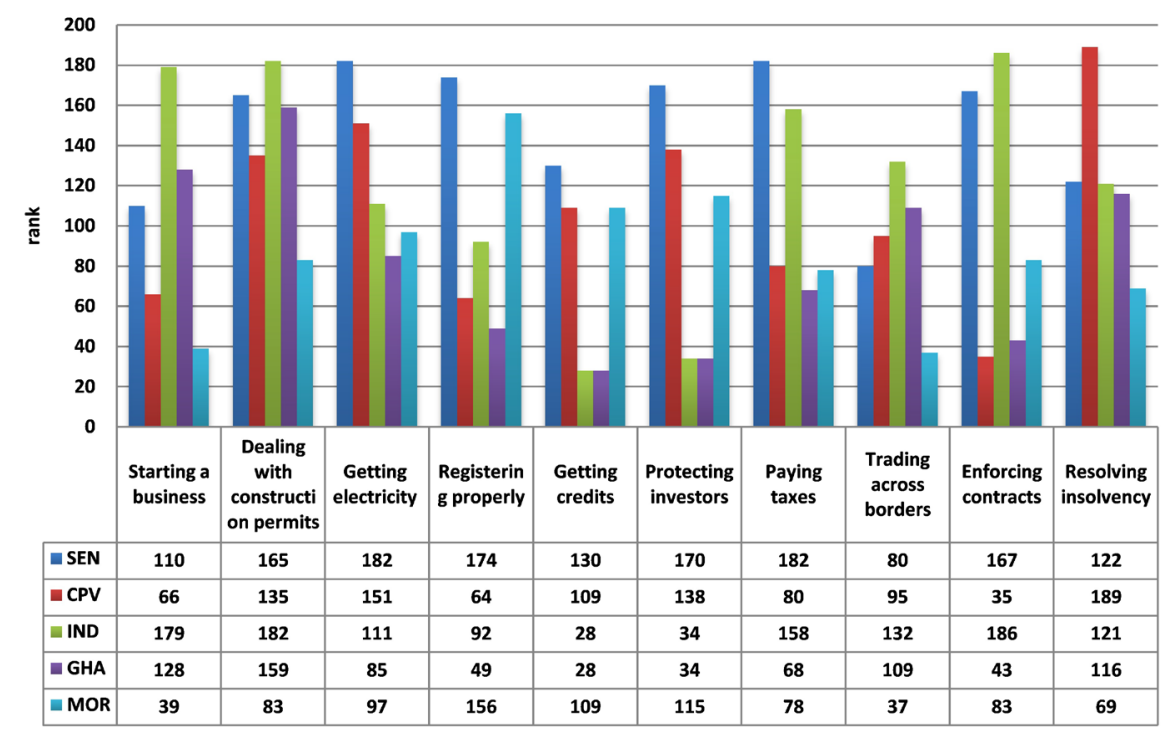

Figure 2. Doing Business ranking, Source: 2014 Doing Business Report, World Bank.

and property registration to reduce the costs and the time spent. The power supply in Senegal has improved since 2007. The average number of electrical panels almost halved from 11.5 panels outages in 2007 to 6 in 2014.

The tax administrations need to ease the tax payment process by shortening the time spent by taxpayers and reducing the number of payments. Bank financing is still limited in Senegal. The proportion of investments financed by banks decreased from $11 \%$ in 2007 to $7 \%$ in 2014 (the average in lower middle income countries is $13 \%$ ). Banks also financed only $7 \%$ of firms working capital, compared to an average of $13 \%$ in lower middle income countries [9] (Senegal WDI 2014).

Additional variables such as informality, corruption and governance, quality, matter when it comes to appreciate business environment quality. 


\section{Literature Review}

In the two and a half centuries since the Industrial Revolution in England, the process of industrialization has perhaps had more impact on all the nations of the world than any other complex set of forces even though that process has not been uniformly introduced in all countries, nor has it occurred at the same time or at the same rate. In this literature review we will try to give a brief conceptual framework before developing the relation between growth and industrialization.

\subsection{Conceptual Framework}

\subsubsection{Concept of Industrialization}

Most of the empirical and theoretical arguments in favour of the concept of industrialization have been summarized by [10] Bolaky (2011). Historically, it represents a transition from an economy based on agriculture to one in which manufacturing represents the principal means of subsistence. Consequently, two dimensions of industrialization are the work that people do for a living (economic activity) and the actual goods they produce (economic output). Other dimensions include the manner in which economic activity is organized (organization). The energy or power source used (mechanization) and the systematic methods and innovative practices employed to accomplish work (technology).

Industrialization has two distinct meanings: it can be conceived as a shift in a country's pattern of output and work force towards manufacturing or secondary industry [11] (Clunies-Ross, Foresyth, \& Huq, 2010). It can also be defined in terms of income levels reaching a certain threshold.

[12] O'Sullivan and Sheffrin (2007) defined industrialization as the process of societal and economic change that transforms a human from agrarian to an industrial one. In their view, industries bring about change in three ways: modernization, the development of large scale energy and metallurgy production. These aspects are closely linked to economic growth. They also assert that industrialization brings with it the sociological process of rationalization.

Overtime, various strategies have been used to promote industrial growth. These are balanced growth, unbalanced growth, import substitution and export promotion.

\subsubsection{Concept of Economy Growth}

The concept of Economic growth has been conceived as an increase in per capita income over a period of time (Clunies-Ross, Foresyth, \& Huq, 2010; [13] Jhingan, 2005; [14] Abbott, 2003).

According to [15] Balami (2006) economic growth, which is always proxy by GDP, is often conceptualized as increase in output of an economy's capacity to produce goods and services needed to improve the welfare of the country's citizens. Growth is seen as a steady process which involves raising the level of output of goods and services in the economy, for example, rise in the Gross Domestic Product (GDP). Growth is meaningful when the rate of growth is much higher than population growth because it has to lead to improvement in human 
welfare. Therefore growth is seen as a steady process of increasing the productive capacity of the economy and hence of increasing national income being characterized by higher rates of per capita output and total factor productivity, especially labors productivity. He also argued that there are three different measurements for economic growth namely: nominal measurement of growth, real output growth rate and growth measured in per capita values.

\subsection{Industrialization as Engine of Economy Growth}

Several empirical studies have supported the assertion of the existence of a relation between industrialization and economic grow even thought the literature evidence is mixed. The older literature aims to accentuate the importance of industrial development, the more recent tends to emphasize the contribution of the service sector, which has increased. Also, the recent literature finds that industry tends to be more important as an engine of growth in developing countries than in advanced economies.

Focusing primarily on the results of conservative [16] Hausman-Taylor estimations, [17] Szirmai and [18] Verspagen's study (1991) focuses on the contribution of manufacturing to GDP per capita growth conditional on the level of education and stage of development. They find that manufacturing acts as an engine of growth for low and for some middle-income countries provided they have a sufficient level of human capital. Such growth engine features are not found for the service sector.

[19] Rodrik (2009) finds a significant positive relationship between growth rates of GDP and shares of industry using regression GDP for five-year periods. He explicitly concludes that transition into modern industrial activities acts as an engine of growth. He argued that the structural transformation is the sole explanation of accelerated growth in the developing world.

For Kaldor (1967), the relationship between industrial development and economic growth and based on empirical results, characterized the manufacturing sector as "the main engine of fast growth". This not only held true for the 12 early industrializers Kaldor examined, from the UK to Japan, but is also characteristic of catching-up countries that have experienced rapid, sustained growth ([20] UNIDO 2013, 2008; Felipe et al., 2014). At high-income levels, and as a standard feature of successful structural change, countries invariably experience deindustrialization, resulting in lower growth rates.

[21] Wim Naudé and Adam Szirmai (2012) have examined the arguments about the engine of growth hypothesis for some Asian and Latin American developing countries. Focusing on capital intensity and growth of output, he finds support for the engine of growth hypothesis, but for some periods capital intensity in services and industry turns out to be higher than in manufacturing. He concludes that in advanced economies productivity growth in agriculture is more rapid than in manufacturing.

A study by [22] Isiksal and Chimezie (2016) indicated that no country particularly the developing ones has attained a level of economic growth without 
sub-sector linkage. They evaluated the Impact of Industrialization in Nigeria from 1997-2012 using the Johansen co-integration testing approach which demonstrated a significant long-run relationship between the three variables used. The results reveal that agriculture, industry and services have a significant positive relationship with GDP.

A study held by [23] Katuria and Raj (2009) in India has examined the engine of growth hypothesis at regional level for the recent period and concludes that more industrialized regions grow more rapidly. On the other hand, [24] Thomas (2009) concludes that services have been the prime mover of growth resurgence in India since the 1990s.

From this brief review of the literature above, it is interesting to note that in spite of the sea of studies on industrialization, controversy over its effect on economic growth, employment and industrial performance persists. However, the use of FDI, nominal exchange rate and degree of openness as proxies for industrialization is gaining wider consensus. Previous studies in Senegal were all case studies of performance of industry business environment in the best of our knowledge, with no consideration of the impact of industrial sector. The present study is an attempt to fill this insufficient research on this topic in Senegal.

\section{Materials and Method}

\subsection{Method of Data Collection}

This section investigates the importance of industrial development in Senegal. The econometric model of Kaldor about the industrial sector as a key of growth will be used in this paper in order to find out the effect of industrial development in Senegalese growth.

The secondary data used in this study were drawn from the World Bank (World Development Indicators WDI 2015), the National Agency of Statistic and Demography in Senegal (ANSD) and covered the period between 1960 and 2017.

The estimation of parameters of the models required data on industrial output, foreign direct investment, foreign exchange rate, Gross Domestic Product and inflation rate. We also used some criteria such as the coefficient of determination (R2), T-test, F-test and Durbin -Watson (DW) statistics which were used to be able to examine the extent of serial correlation between variables.

\subsection{Model Specification}

The OLS Ordinary Least Square method was used in the estimation of the coefficients of the explanatory variables in order to test the influence of the independent variables on the dependent variable.

The first law of Kaldoris that there is a positive relationship between industrial output and GDP growth. This equation below presented the first law of Kaldor

$$
q_{i}=\beta_{i}+b_{i} m_{i}
$$

where $q$ and $m$ refer respectively to the growth of total output and industrial 
output. The subscript $g$ indicates the growth over the period of time or study period. Let $q$ be represented by GDP and $\mathrm{m}$ by IND.

In order to find out if there are others factors that might affect the economy growth in Senegal, it is necessary to add some controls variables.

The new model specification will be in the general form as:

$$
\mathrm{GDP}=f(\mathrm{IND}, \mathrm{INF}, \mathrm{FDI}, \mathrm{FER})
$$

where,

GDP $=$ Gross Domestic Product at current basic prices;

IND = Industrial Output;

$\mathrm{INF}=$ Inflation Rate;

FDI = Foreign Direct Investment;

FER = Foreign Exchange Rate.

The econometric form of the model is summarized as a functional relationship below: GDP $=f($ IND, INF, FDI, FER $)$.

In stating the relationship mathematically, we get

$$
\mathrm{GDP}=\beta 0+\beta 1 \mathrm{IND}+\beta 2 \mathrm{INF}+\beta 3 \mathrm{FDI}+\beta 4 \mathrm{FER}=0
$$

Stating the relationship in an econometric model, it becomes

$$
\mathrm{GDP}=\beta 0+\mathrm{IND}+\mathrm{INF}+\mathrm{FDI}+\mathrm{FER}+U_{i}
$$

where; $\beta 0$ is the constant intercept which shows the level of GDP, when the explanatory variables IND, FER, FDI and INF are zero.

\section{Result and Discussion}

This model employs the OLS multiple regression to test the relationship between Gross domestic Product (GDP) and the independent variables IND, INF, FER and FDI. Table 1 summarizes the OLS regression results.

The model results in Table 1 show that only the industrial output, the foreign direct investment and the constant rate have positive impact on the dependent variable GDP. The implication is that a $1 \%$ increase in industrial output, FDI and the constant will lead to corresponding increase in the endogenous variable GDP by $4.475,1.956$ and 9.62 respectively.

However, the foreign exchange rate and the inflation rate have negative relationship with the dependent variable GDP. This means that as FER and INF rise by $1 \%$, the gross domestic product will fall respectively by -1.249 and -6.825 .

We can also record from the results, that only the explanatory variable inflation rate is individually not statistically significant in the explanation of the dependent variable since the absolute value of its t-statistic of -1.411 is less than the conventional value of 2.056 at $5 \%$ level of significance. The constant was found statistically significant at 1 percent as indicated by its probability value of 0.0000 , which suggested that there are others variables that significantly and positively affected GDP but were not captured in this model.

Test of Goodness of Fit (R2)

Talking about the performance of the estimated model, it may be noted ac- 
cording to the results, that the coefficient of determination R2 is 0.997 showing that the model was statistically significant. This means that industry output, FDI, inflation rate, FER as well as a constant rate, explain collectively about $99 \%$ the level of output growth in Senegal for the period 1960-2017.

F-statistics

Note that the F-ratio is statistically highly significant as shown by the F-statistics estimations for 354.871 with a probability of 0.0000 . This means simply that the R2 value of 0.997 is different from zero. At the level of $100 \%$ confidence, the explanatory variables industrial output, FDI, FER and inflation were jointly and significantly affecting economic growth in Senegal. Therefore we conclude that industrial development has significant effect on economic growth in Senegal during the period 1960-2017.

The Durbin-Watson statistic 1.287 is observed to be higher than R2 0.997 and less than 2 indicating that the model is non-spurious (meaningful) and the presence of/or positive autocorrelation. We, therefore conduct Breusch-Godfrey serial correlation LM test and Breusch-Pagan-Godfrey heteroskedasticity test.

Table 2 describes the existence or not of heteroskedasticity, which is a major concern in the application of regression analysis, including the analysis of variance.

Heteroskedasticity test: Breusch-Pagan-Godfrey

Null hypothesis: Homoskedasticity

The Heteroskedasticity test results contain in Table 2 shows that the variance of the error terms is constant as indicated by the F-probability value of 0.1592 . Therefore, we can reject the null hypothesis that the variance of the residuals is constant and accept the null hypothesis of no heteroskedasticity at 5 per cent significant level.

Table 3 contains the results of the serial correlation test, which is a test for

Table 1. OLS regression test.

\begin{tabular}{ccccc}
\hline Variable & Coefficient & Std. Error & t-Statistic & Prob. \\
IND & 4.475025 & 0.093646 & 47.78665 & 0.0000 \\
FDI & 1.956548 & 0.701944 & -2.787328 & 0.0205 \\
INF & -6.825698 & 4.837016 & -1.411138 & 0.1668 \\
FER & -1.249869 & 2.475187 & -5.049592 & 0.0084 \\
C & 9.624208 & 1.313208 & 7.328689 & 0.0000 \\
R-squared & 0.997470 & Mean dependent & $6.35 \mathrm{E}+09$ \\
Adjusted R-squared & 0.997189 & S.D. dependent variable & $4.04 \mathrm{E}+09$ \\
S.E. of regression & 2.650118 & Akaike info criterion & 41.31583 \\
Sum squared residuals & 1.651318 & Schwarz criterion & 41.52480 \\
Log likelihood & -841.9746 & F-statistic & 1.287574 \\
Durbin-Watson stat & 1.287574 & Prob (F-statistic) & 0.000000
\end{tabular}

Source: researcher's own computation. 
Table 2. Heteroskedasticity test.

\begin{tabular}{cccc}
\hline F-statistic & 1.755931 & Prob. F $(4,36)$ & 0.1592 \\
\hline Obs $^{*}$ R-squared & 6.693345 & Prob. Chi-Square (4) & 0.1530 \\
Scaled explained SS & 4.540379 & Prob. Chi-Square (4) & 0.3378 \\
\hline
\end{tabular}

Source: researcher's own computation.

Table 3. Breusch-godfrey serial correlation LM test.

\begin{tabular}{cccc}
\hline F-statistic & 2.914214 & Prob. F $(2,34)$ & 0.0679 \\
\hline Obs $^{\star}$ R-squared & 5.999874 & Prob. Chi-Square (2) & 0.0498 \\
\hline
\end{tabular}

Source: researcher's own computation.

autocorrelation model. It makes use of the residuals from the model being considered in a regression in a regression analysis.

Breusch-Godfrey serial correlation LM test:

Null hypothesis: No Serial correlation at up to 2 lags.

The Serial Correlation LM test results contain in Table 3 rejects the hypothesis of no serial correlation between the error terms as indicated by the F-probability value of 0.0679 implying that the residuals are serially correlated and therefore we accept the null hypothesis of no serial correlation at 5\% significant level.

\section{Conclusions and Recommendations}

The principal objective of this study is the examination of the impact of industrialization on economy growth in Senegal using the World Bank (WDI 2015) dataset. This paper aims to help to better understand the Sub-Saharan African countries' industrialization. Most of those countries are underrepresented in most statistical exercises and databases, because long-run time series are not easily available and they have had very weak industrial performance as well as disappointing rates of economic growth, therefore, including them more in the analysis would strengthen rather than weaken the case for the engine of growth.

The main finding is that industrial development has significant effect on economic growth in Senegal during the period 1960-2017. Industrialization will go a long way in stimulating economic growth in Senegal. However, the importance of industrialization to economic growth can't be overemphasized according to the study result. The import substitution industrialization strategy adopted from 1960 till present, has failed to achieve both internal and external balance because of lack of technological base and structural problem in particular.

Therefore, we would recommend some policy measures in order to boost industrial output by improving the overall productivity of all the sectors and ensure sustainable development. The government should create a good environment for industrial growth through:

- Provide conducive investment environment by removing the structural rigidities that exist in the economy to encourage industrial activities. 
- Provide stable supply of power, good roads for transportation of goods and people, functional legal system, security of lives and property, infrastructural facilities etc.

- Provision of good governance mechanism and a good legal framework to protect property rights.

- Improve on social and economic infrastructure, especially electricity supply and functional education. This can reduce the cost of production.

- Improve diffusion of technology and make Senegalese manufacturers more competitive.

- Improve the quality of the work factor and the financing of firms (especially SMEs/SMIs).

- Fight against corruption and the further improvement of the regulatory framework to reduce the operating costs of firms.

\section{Conflicts of Interest}

The authors declare no conflicts of interest regarding the publication of this paper.

\section{References}

[1] Pacheco-López, P. and Thirlwall, A.P.(2013) A New Interpretation of Kaldor's First Growth Law for Open Developing Economies. University of Kent, School of Economics Discussion Papers, KDPE 1312.

[2] Szirmai, A. (2012) Industrialisation as an Engine of Growth in Developing Countries 1950-2005. Structural Change and Economic Dynamics, 23, 406-420. https://doi.org/10.1016/j.strueco.2011.01.005

[3] Kaldor, N. (1967) Strategic Factors in Economic Development. Cornell University Press, Ithaca, NY.

[4] (2012) World Bank World Development Indicators Online. http://databank.worldbank.org/ddp/home.do?Step=12\&id=4\&CNO=2

[5] Abiola, M.E. (2012) Savings, Investment, Productivity and Economic Growth in Nigeria. Journal of Research in National Development, No. 2, 356-374.

[6] Republique du Senegal (2005) Lettre de politique sectorielle dedéveloppement de l'industrie: La politique deredéploiement industriel.

[7] ANSD Senegal (2016) Rapport final de l'enquêtesurl'état des lieux de l'industrie au Sénégal.

[8] Doing Business Report, World Bank (2014).

[9] World Bank (2014) Senegal Country Profile, 2014 Enterprise Surveys.

[10] Bolaky, B. (2011) The Role of Industrialisation in Economic Development: Theory and Evidence. UNCTAD, 52.

[11] Clunies-Ross, A., Foresyth, O. and Huq, M. (2010) Development Economics. McGraw Hill, London.

[12] O’Sullivan, A. and Sheffrin, S. (2007) Economics: Principles in Action. Prentice Hall, New Jersey.

[13] Jhingan, M. (2005) Economics of Development and Planning. Vrinda Publications, Delhi.

[14] Abbott, L. (2003) Theories of Industrialization and Enterprise Development. Good 
Book, London.

[15] Balami, D.H. (2006) Macroeconomic Theory and Practice. Salawe Prints, Off Leventies, Wulari, Maiduguri.

[16] Hausman, J.A. and Taylor, W.E. (1981) Panel Data and Unobservable Individual Effects. Econometrica, 49, 1377-1398. https://doi.org/10.2307/1911406

[17] Szirmai, A. (2012) Development Statistics, Figure 4.1. http://www.dynamicsofdevelopment.com

[18] Verspagen, B. (1991) A New Empirical Approach to Catching up or Falling behind. Structural Change and Economic Dynamics, No. 2, 359-380. https://doi.org/10.1016/S0954-349X(05)80008-6

[19] Rodrik, D. (2009) Growth after the Crisis. Harvard Kennedy School, Cambridge.

[20] UNIDO (2013) Sustaining Employment Growth: The Role of Manufacturing and Structural Change. Industrial Development Report, UNIDO, Vienna.

[21] Naudé, W. and Szirmai, A. (2012) The Importance of Manufacturing in Economic Development: Past, Present and Future Perspectives.

[22] Isiksal, A.Z. and himezie, O.J. (2016) Impact of Industrialization in Nigeria. European Scientific Journal, 12.

[23] Katuria, V. and Raj, R.S.N. (2009) Is Manufacturing an Engine of Growth in India? Analysis in the Post Nineties. UNU-WIDER/UNU-MERIT/UNIDO Workshop, Pathways to Industrialisation in the 21 st Century, New Challenges and Emerging Paradigms, Maastricht, 22-23 October 2009.

[24] Thomas, J.J. (2009) Why Is Manufacturing Not the Engine of India's Economic Growth, Examining Trends, 1959-60 to 2008/9. Mimeo, New Delhi. 